... Istek, Aydin, Ozlusoylu: The Effect of Mat Layers Moisture Content on Some Properties...

Abdullah Istek', Ufuk Aydin², Ismail Ozlusoylu ${ }^{1}$

\title{
The Effect of Mat Layers Moisture Content on Some Properties of Particleboard
}

\section{Utjecaj sadržaja vode u slojevima ploče iverice na njezina svojstva}

\author{
Original scientific paper • Izvorni znanstveni rad \\ Received-prispjelo: 25. 5. 2018. \\ Accepted-prihvaćeno: 4. 7. 2019. \\ UDK: $630 * 812.462 ; 630 * 812.7 ; 630 * 861.232$ \\ https://doi.org/10.5552/drvind.2019.1821
}

\begin{abstract}
In this study, the effect of mat moisture content on the physical and mechanical properties of particleboard was investigated. The experimental boards were produced by using $40 \%$ softwood, $45 \%$ hardwood chips, and $15 \%$ sawdust. The formaldehyde resin/adhesive was used in three-layers (bottom-top layer $12 \%$, core layer $8 \%$ ). Multi-opening press was used during manufacturing the experimental particleboards. The physical and mechanical properties of boards obtained were identified according to the TS-EN standards. The optimum core layer moisture content was determined as $6 \%$ and $7 \%$ according to the results, whereas the moisture content of bottom and top layers was $14 \%$. Under these moisture content conditions, the bending strength was found to be $13.3 \mathrm{~N} / \mathrm{mm}^{2}$, the modulus of elasticity in bending $2466 \mathrm{~N} / \mathrm{mm}^{2}$, and internal bonding strength $0.44 \mathrm{~N} / \mathrm{mm}^{2}$. The optimum bottom-top layer moisture content was determined to be between $13 \%$ and $15 \%$ and $6.5 \%$ for the core layer.
\end{abstract}

Keywords: wood-based panels; particleboard; mat moisture content; properties

SAŽETAK・U radu je istraživan utjecaj sadržaja vode u slojevima ploča od usitnjenog drva na njihova fizička i mehanička svojstva. Istraživane su ploče proizvedene od iverja mekog drva u udjelu $45 \%$, iverja tvrdog drva $u$ udjelu $15 \%$ i drvne prašine u udjelu $15 \%$. Ploče su se sastojale od tri sloja u kojima je upotrijebljena formaldehidna smola/ljepilo (u vanjskim slojevima $12 \%$, u središnjim slojevima $8 \%$ ), a prešanje je obavljeno višeetažnom prešom. Fizička i mehanička svojstva ploča određena su prema TS-EN normama. Iz dobivenih je rezultata utvrđen optimalan sadržaj vode u središnjem sloju od 6 i $7 \%$, dok je konstantni sadržaj vode u vanjskim slojevima iznosio $14 \%$. Pri tim sadržajima vode dobiveni su ovi rezultati: čvrstoća na savijanje 13,3 N/mm², modul elastičnosti 2466 $\mathrm{N} / \mathrm{mm}^{2}$ i međuslojna čvrstoća $0,44 \mathrm{~N} / \mathrm{mm}^{2}$. Utvrđeno je da je optimalan sadržaj vode u vanjskim slojevima između 13 i $15 \%$, a u središnjem sloju $6,5 \%$.

Ključne riječi: drvne ploče, ploča od usitnjenog drva, sadržaj vode u slojevima ploče, svojstva

\section{INTRODUCTION 1. UVOD}

Particleboards (PB) are manufactured under heat and pressure of mat obtained from wood particles or other lignocellulosic material in particle with the addi- tion of an adhesive. PB properties can be changed with some factors such as adhesive bonding, particle geometry, resin type and density variations due to random particle deposition during mat forming (Sanabria et al., 2013; İstek et al., 2010). The most important factors

\footnotetext{
${ }^{1}$ Authors are professor and researcher at the Bartin University, Faculty of Forestry, Department of Forest Industrial Engineering, Bartin, Turkey. ${ }^{2}$ Author works at the Kastamonu Integrated Particleboard Factory, Turkey.

${ }^{1}$ Autori su profesor i istraživač Sveučilišta Bartin, Šumarski fakultet, Zavod za inženjerstvo u šumarstvu, Bartin, Turska.

${ }^{2}$ Autor je zaposlen u tvornici ploča od usitnjenog drva Kastamonu Integrated, Turska.
} 
affecting the properties of board at the stage of pressing are the mat moisture, temperature, specific press pressure, press closing speed, and pressing duration. In a previous study, it was determined that, at $11 \%$ mat moisture and mat thickness increased from $20 \mathrm{~mm}$ to $40 \mathrm{~mm}$, the duration of core layer temperature increase to $100{ }^{\circ} \mathrm{C}$ was prolonged by 4 times (Hata, 1993). It was reported that the mat moisture content plays an important role in properties of MDF produced using phenol formaldehyde (FF) resin, and that the mean characteristics achieved at $12 \%$ mat moisture content were found to be better than those obtained at $6 \%$ and $9 \%$ mat moistures (Chow and Zhao, 1992). The mat moisture contents higher than the limit were reported to cause bursting risk in PB production, while the lower contents caused brittle fracture following the pressing (Bardak, 2010; Kollmann et al., 1975). It was reported that moist PB mat is plasticized under the effects of temperature and pressure in pressing, which results in a stable structure (Güler and Sanca, 2016; SedanoMendoza et. al., 2010). The moisture of mat PB before the hot pressing is one of the most important factors affecting the heat transfer within mat, as well as the properties of PB (Park et al., 1999).

In $\mathrm{PB}$ production, the mean mat moisture is calculated by taking the particle concentration and core layer moisture into consideration since the surface layers and core layer have different moisture contents. The mat moisture plays a significant role in the surface smoothness and soundness of PB, the bubbling on surface during the pressing, and the production costs. In case of too low moisture in particles, the resin is absorbed by the particles and there may be insufficient resin in the medium for the required adhesion level (Lynam, 1969; Akbulut, 1998). In this case, no sufficient bond can be established on the surface layers of boards, and the board surface becomes loose and weak. High moisture content, on the other hand, may cause the burst of board after the pressing procedure (Lynam, 1969). During the board production, the water is sometimes sprayed on the mat surfaces in order to shorten the pressing time, to eliminate the prehardening, and to improve the surface structure (Kollmann et al., 1975). If the mat contained too much moisture, the board would contain visible and open vapor bubbles. As a result of that, the parallel shear resistance of surface decreases, and the moisture content of board increases. In order to prevent or minimize such results, longer pressing is required (Lynam, 1969). It was reported that, prior to the pressing procedure, if the mean mat moisture is higher than 15-16 $\%$, the moisture cannot be vaporized sufficiently by using a short pressing time for the boards with the density of $0.65 \mathrm{gr} / \mathrm{cm}^{3}$ and, in addition to insufficient vaporization, the board will also burst from the core layer (Huş, 1979). In another study, it was emphasized that the high level of mat moisture content during the hot pressing procedure increased the formaldehyde emission (Kollman et al., 1975; Roffael, 1982). Nemli et al. (2007) reported that, in PB production, the mat moisture contents higher than $13 \%$ caused lower technological properties in boards. In another study, it was found that the mat moisture content in MDF board production plays an important role in internal bond strength (IB) and thickness (Hague et al., 1999).

The aim of this study was to investigate the effects of mat moisture content on the physical and mechanical properties of $\mathrm{PB}$, and to determine the ideal mat moisture content for 3-layered PB production. The ultimate aim was to increase the production quality and to decrease the costs.

\section{MATERIALS AND METHODS 2. MATERIJALI I METODE}

The experimental boards used in this study were produced in a company's production line in Kastamonu, Turkey. All of the production parameters used in manufacturing the experimental boards are the same as those used in company's products; the materials consist of $40 \%$ black pine (Pinus nigra), $30 \%$ sessile oak (Quercus petraea), $15 \%$ poplar (Populus alba), and 15 $\%$ sawdust (90\% pine-10\% poplar). Particles were dried at $170{ }^{\circ} \mathrm{C}$ by using rotary drum dryer to reach the target moisture content (MC) at $1 \%-2 \%$. Urea formaldehyde (UF), which was used as adhesive, consists of $(62 \pm 1) \%$ solid matter and its $\mathrm{pH}$ is $8.2 \mathrm{pH}$. This material was also produced in the same facility. As a hardener, $20 \%$ ammonium chloride $\left(\mathrm{NH}_{4} \mathrm{Cl}\right)$ solution was used based on $2.5 \%$ of resin solid weight for the core layers and $1 \%$ of resin solid weight for the surface layers. The experimental boards were produced in multi opening press, and mat moisture contents are presented in Table 1, while the production conditions are specified in Table 2 .

In determining the physical and mechanical properties of experimental boards, the Turkish standards that are compatible with European norms were used, and the results are presented in Table 3.

Table 1 Mat moisture content of experimental boards

Tablica 1. Sadržaj vode u istraživanim pločama

\begin{tabular}{|c|c|c|c|}
\hline \multirow{2}{*}{$\begin{array}{c}\text { Board type } \\
\text { Vrsta ploče }\end{array}$} & \multirow{2}{*}{$\begin{array}{c}\text { Board } \\
\text { replications } \\
\text { Broj ploča }\end{array}$} & $\begin{array}{c}\text { Mat moisture content, \% } \\
\text { Sadržaj vode, \% }\end{array}$ \\
\cline { 3 - 4 } & $\begin{array}{c}\text { Core layer } \\
\text { Središnji sloj }\end{array}$ & $\begin{array}{c}\text { Outer layers } \\
\text { Vanjski slojevi }\end{array}$ \\
\hline A & 3 & 5.5 & 14 \\
\hline B & 3 & 6 & 14 \\
\hline C & 3 & 6.5 & 14 \\
\hline D & 3 & 7 & 14 \\
\hline E & 3 & 7.5 & 14 \\
\hline F & 3 & 8 & 14 \\
\hline G & 3 & 6.5 & 12 \\
\hline H & 3 & 6.5 & 13 \\
\hline I & 3 & 6.5 & 14 \\
\hline J & 3 & 6.5 & 15 \\
\hline K & 3 & 6.5 & 16 \\
\hline L & 3 & 6.5 & 17 \\
\hline
\end{tabular}


... Istek, Aydin, Ozlusoylu: The Effect of Mat Layers Moisture Content on Some Properties...

Table 2 Production conditions of experimental boards

Tablica 2. Uvjeti proizvodnje istraživanih ploča

\begin{tabular}{|l|c|}
\hline Characteristics / Svojstva & $\begin{array}{c}\text { Production conditions } \\
\text { Uvjeti proizvodnje }\end{array}$ \\
\hline Board thickness / debljina ploče, $\mathrm{mm}$ & 18 \\
\hline Board width - length / širina i duljina ploče, $\mathrm{mm}$ & $2100-2800$ \\
\hline Board density / gustoća ploče, $\mathrm{kg} / \mathrm{m}^{3}$ & 605 \\
\hline Core layer chip ratio / udio iverja u središnjem sloju, \% & 62 \\
\hline Bottom-top layer chip ratio / udio iverja u gornjem i donjem sloju, \% & $19-19$ \\
\hline Press temperature / temperatura prešanja, ${ }^{\circ} \mathrm{C}$ & 180 \\
\hline Press pressure / tlak prešanja, $\mathrm{kg} / \mathrm{cm}^{2}$ & 30 \\
\hline Total press time / ukupno vrijeme prešanja, s & 180 \\
\hline Bottom-top layer resin ratio / udio smole u gornjem i donjem sloju, $\%$ & 12 \\
\hline Core layer resin ratio / udio smole u središnjem sloju, $\%$ & 8 \\
\hline
\end{tabular}

Table 3 Test standards used to determine physical and mechanical properties

Tablica 3. Norme prema kojima su određena fizička i mehanička svojstva ploča

\begin{tabular}{|l|c|}
\hline Sampling, cutting and inspection / Uzorkovanje, krojenje i provjera & TS EN 326-1 (1999) \\
\hline Determination of density / Određivanje gustoće & TS EN 323 (1999) \\
\hline $\begin{array}{l}\text { Determination of swelling in thickness after immersion in water (2 hours) } \\
\text { Određivanje debljinskog bubrenja nakon potapanja u vodi (2 sata) }\end{array}$ & TS EN 317 (1999) \\
\hline $\begin{array}{l}\text { Determination of tensile strength perpendicular to the plane of the board } \\
\text { Određivanje vlačne čvrstoće okomito na površinu ploče }\end{array}$ & TS EN 319 (1999) \\
\hline $\begin{array}{l}\text { Determination of modulus of elasticity in bending and of bending strength } \\
\text { Određivanje čvrstoće na savijanje i modula elastičnosti čvrstoće na savijanje }\end{array}$ & TS EN 310 (1999) \\
\hline $\begin{array}{l}\text { Determination of resistance to axial withdrawal of screws } \\
\text { Određivanje otpora pri okomitom vađenju vijaka }\end{array}$ & TS EN 320 (2011) \\
\hline Surface soundness / Međuslojna čvrstoća & TS EN 311 (2005) \\
\hline
\end{tabular}

\section{RESULTS AND DISCUSSION}

\section{REZULTATI I RASPRAVA}

The effects of moisture content changes on the physical and mechanical properties were determined by keeping the mat moisture content of core layer at $6.5 \%$ and by applying various moisture contents of bottom-top layers, and keeping the bottom-top layer moisture at $14 \%$ and applying various moisture contents of core layer. The results are shown in Table 4.

When the mat moisture content of bottom-top and core layers was fixed at $14 \%$ and $8 \%$, respective$1 y$, it was observed that the board generally burst at the end of hot press. Similarly, when the mat moisture of core layer was kept constant at $6.5 \%$ and mat moisture contents of bottom-top layer were adjusted at $17 \%$, some of the boards burst when leaving the hot press in test production.

The densities of experimental boards were observed to vary between 600 and $609 \mathrm{~kg} / \mathrm{m}^{3}$, and the density differences between the boards were at negligibly low levels. It was reported that the boards with density differences less than $10 \%$ (TS EN 312) would exhibit similar mechanical properties and remain within the same group of boards (İstek and Siradağ, 2013). The effects of mat moisture content changes in particleboard production on the water absorption and swelling properties are presented in Figures 1 and 2.

As shown in Figure 1, as the top and bottom surface mat moisture contents increased from $12 \%$ to 15 $\%$, the water absorption characteristics of particleboards improved and increased again at 16 and $17 \%$

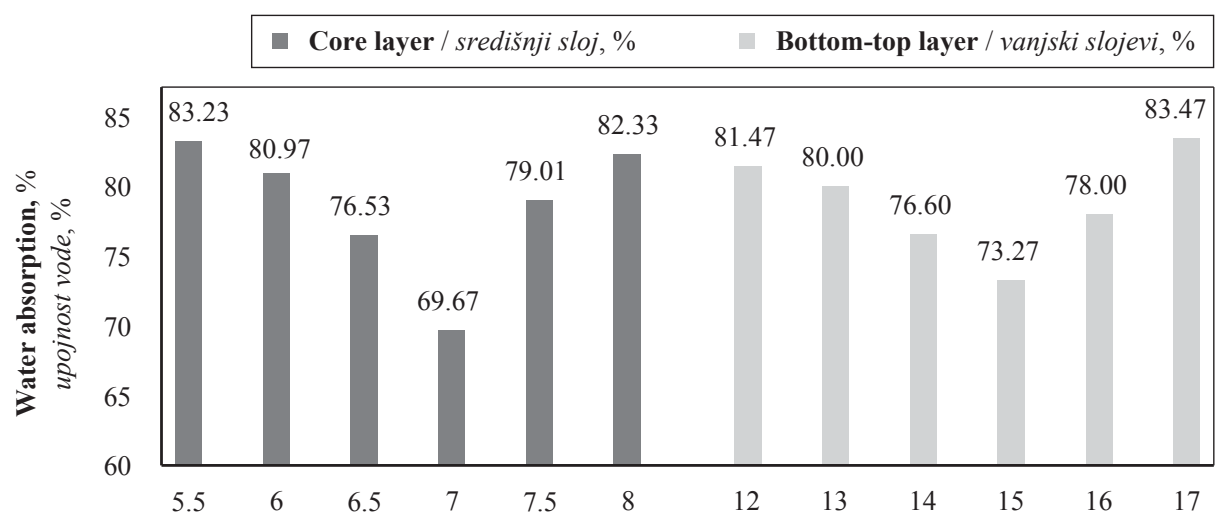

Figure 1 The effects of mat layers moisture content changes on water absorption (2h) characteristics

Slika 1. Utjecaj promjene sadržaja vode u slojevima ploče na upojnost vode (2h) 
Table 4 Effects of mat moisture changes on particleboard properties

Tablica 4. Utjecaj promjene sadržaja vode u slojevima ploče na njezina svojstva

\begin{tabular}{|c|c|c|c|c|c|c|c|c|c|}
\hline \multicolumn{2}{|c|}{$\begin{array}{l}\text { Moisture value } \\
\text { Sadržaj vode, \% }\end{array}$} & $\begin{array}{c}\text { Density } \\
\text { Gustoća } \\
\mathrm{kg} / \mathrm{m}^{3}\end{array}$ & $\begin{array}{c}\text { Water } \\
\text { absorp- } \\
\text { tion } \\
(\mathbf{2 h}) \\
\text { Upojnost } \\
\text { vode }(2 \mathrm{~h}) \\
\% \\
\end{array}$ & $\begin{array}{c}\text { Thickness } \\
\text { swelling } \\
\text { (2h) } \\
\text { Debljinsko } \\
\text { bubrenje } \\
\text { (2h), \% }\end{array}$ & $\begin{array}{l}\text { Internal } \\
\text { bonding } \\
\text { strength } \\
\check{C} \text { vrstoća } \\
\text { raslojavanja } \\
\mathrm{N} / \mathrm{mm}^{2}\end{array}$ & $\begin{array}{l}\text { Bending } \\
\text { strength } \\
\check{C} \text { vrstoća } \\
\quad \text { na } \\
\text { savijanje } \\
\mathrm{N} / \mathrm{mm}^{2}\end{array}$ & $\begin{array}{c}\text { Modulus of } \\
\text { elasticity in } \\
\text { bending } \\
\text { Modul } \\
\text { elastičnosti } \\
\text { pri savijanju } \\
\mathrm{N} / \mathrm{mm}^{2} \\
\end{array}$ & $\begin{array}{c}\text { Screw } \\
\text { with- } \\
\text { drawal } \\
\text { Otpor } \\
\text { vađenju } \\
\text { vijaka } \\
\mathrm{N} / \mathrm{mm}^{2} \\
\end{array}$ & 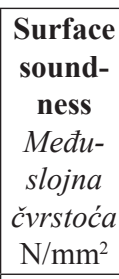 \\
\hline \multirow{6}{*}{$\begin{array}{l}\text { Mat moisture } \\
\text { changes of core } \\
\text { layer / promjena } \\
\text { sadržaja vode u } \\
\text { središnjem sloju }\end{array}$} & 5.5 & $\begin{array}{c}603 \\
(4.58) \\
\end{array}$ & $\begin{array}{l}83.23 \\
(1.66)\end{array}$ & $\begin{array}{l}14.20 \\
(0.17)\end{array}$ & $0.34(0.02)$ & $\begin{array}{l}11.83 \\
(0.15)\end{array}$ & $2140(61.85)$ & $\begin{array}{c}526 \\
(20.82) \\
\end{array}$ & $\begin{array}{c}0.94 \\
(0.03) \\
\end{array}$ \\
\hline & 6 & $\begin{array}{c}607 \\
(2.65) \\
\end{array}$ & $\begin{array}{l}80.97 \\
(0.25) \\
\end{array}$ & $\begin{array}{l}13.23 \\
(0.25) \\
\end{array}$ & $0.39(0.02)$ & $\begin{array}{l}12.83 \\
(0.15) \\
\end{array}$ & $2315(17.35)$ & $\begin{array}{c}623 \\
(8.08)\end{array}$ & $\begin{array}{l}1.13 \\
(0.02)\end{array}$ \\
\hline & 6.5 & $\begin{array}{c}605 \\
(1.15) \\
\end{array}$ & $\begin{array}{l}76.53 \\
(1.14)\end{array}$ & $\begin{array}{l}12.37 \\
(0.12)\end{array}$ & $0.44(0.01)$ & $\begin{array}{l}13.13 \\
(0.29)\end{array}$ & $2424(36.68)$ & $\begin{array}{c}630 \\
(10.02)\end{array}$ & $\begin{array}{l}1.08 \\
(0.02)\end{array}$ \\
\hline & 7 & $\begin{array}{c}602 \\
(2.52) \\
\end{array}$ & $\begin{array}{l}69.67 \\
(1.53) \\
\end{array}$ & $\begin{array}{l}11.87 \\
(0.15) \\
\end{array}$ & $0.34(0.03)$ & $\begin{array}{l}12.01 \\
(0.20)\end{array}$ & $2136(48.23)$ & $\begin{array}{c}593 \\
(6.66)\end{array}$ & $\begin{array}{c}0.94 \\
(0.04)\end{array}$ \\
\hline & 7.5 & $\begin{array}{c}609 \\
(2.65) \\
\end{array}$ & $79.01(2)$ & $\begin{array}{c}13.4 \\
(0.53) \\
\end{array}$ & $0.26(0.02)$ & $\begin{array}{l}11.17 \\
(0.12) \\
\end{array}$ & $1972(57.62)$ & $\begin{array}{c}514 \\
(4.04)\end{array}$ & $\begin{array}{c}0.80 \\
(0.03)\end{array}$ \\
\hline & 8 & 201 & 29.33 & & 0.04 & 3.03 & 503 & 70 & 0.23 \\
\hline \multirow{6}{*}{$\begin{array}{c}\text { Mat moisture } \\
\text { changes of } \\
\text { bottom-top } \\
\text { Layer / promjena } \\
\text { sadržaja vode u } \\
\text { vanjskim } \\
\text { slojevima }\end{array}$} & 12 & $602(3)$ & $\begin{array}{l}81.47 \\
(1.10)\end{array}$ & $\begin{array}{l}13.03 \\
(0.06)\end{array}$ & $0.35(0.02)$ & $\begin{array}{l}11.27 \\
(0.45)\end{array}$ & $2117(2.52)$ & $\begin{array}{c}593 \\
(3.51)\end{array}$ & $\begin{array}{c}0.85 \\
(0.03)\end{array}$ \\
\hline & 13 & $\begin{array}{c}608 \\
(5.51)\end{array}$ & $80(0.20)$ & $\begin{array}{l}12.80 \\
(0.10)\end{array}$ & $0.38(0.02)$ & $\begin{array}{l}12.17 \\
(0.25)\end{array}$ & $2219(6.66)$ & $\begin{array}{c}612 \\
(2.52)\end{array}$ & $\begin{array}{c}1.01 \\
(0.04)\end{array}$ \\
\hline & 14 & $\begin{array}{c}605 \\
(4.73)\end{array}$ & $\begin{array}{l}76.60 \\
(0.53)\end{array}$ & $\begin{array}{l}12.43 \\
(0.06)\end{array}$ & $0.41(0.01)$ & $\begin{array}{l}12.70 \\
(0.53) \\
\end{array}$ & $2398(41.62)$ & $\begin{array}{c}633 \\
(5.29) \\
\end{array}$ & $\begin{array}{c}1.12 \\
(0.03) \\
\end{array}$ \\
\hline & 15 & $605(3)$ & $\begin{array}{l}73.27 \\
(0.64)\end{array}$ & $\begin{array}{l}12.10 \\
(0.10)\end{array}$ & $0.38(0.01)$ & $\begin{array}{l}12.83 \\
(0.15)\end{array}$ & 2337 (7.64) & $\begin{array}{c}618 \\
(1.53)\end{array}$ & $\begin{array}{c}1.13 \\
(0.02)\end{array}$ \\
\hline & 16 & $\begin{array}{c}600 \\
(2.52)\end{array}$ & $78(0.80)$ & $\begin{array}{l}12 . .73 \\
(0.25)\end{array}$ & $0.35(0.01)$ & $\begin{array}{l}12.93 \\
(0.15)\end{array}$ & $2161(4.58)$ & $\begin{array}{c}592 \\
(2.65)\end{array}$ & $\begin{array}{c}1.03 \\
(0.02)\end{array}$ \\
\hline & 17 & 402 & $55(47.83)$ & 9.50 & $0.17(0.15)$ & $\begin{array}{c}6.87 \\
(6.18)\end{array}$ & 986 & 277 & $\begin{array}{c}0.55 \\
(0.48)\end{array}$ \\
\hline
\end{tabular}

The values in parentheses indicate the standard deviation. / Vrijednosti u zagradama standardne su devijacije.

moisture contents. As the mat moisture contents of core layer increased from $5.5 \%$ to $7 \%$, the water absorption decreased and then increased again to $7.5-8$ $\%$ moisture content level. The moisture content of the glued particle board sample should never exceed $10-$ $13 \%$ for core layer and $15-18 \%$ for bottom-top layer, so that the moisture contents of core layer would not exceed the level of $13 \%$ (Hus, 1979). Moreover, since the moisture cannot be sufficiently vaporized, this prevents the hardening of resin at core layer, the bonding between the particles in this section decreases and then the water absorption increases (Nemli et al., 2007).

The effects of mat moisture content changes on the thickness swelling ( $2 \mathrm{~h}$ ) characteristics, as seen in Figure
2, show similarities with those on water absorption. Thus, by examining the effects of mat moisture content changes on the water absorption and thickness swelling, the optimal production conditions were determined to be $7 \%$ for core layer moisture and $15 \%$ for bottom-top layer moistures. It was reported that, when the mean mat moisture content increased from $13 \%$ to $17 \%$, the thickness swelling was negatively affected (Nemli et al., 2007). The effects of mat moisture changes in particleboard production on IB are presented in Figure 3.

Figure 3 indicated that, together with the increase of core layers mat moisture from $5.5 \%$ to $6.5 \%$, it was determined that the IB strength of particleboard increased and started to decrease after $7 \%$ moisture con-

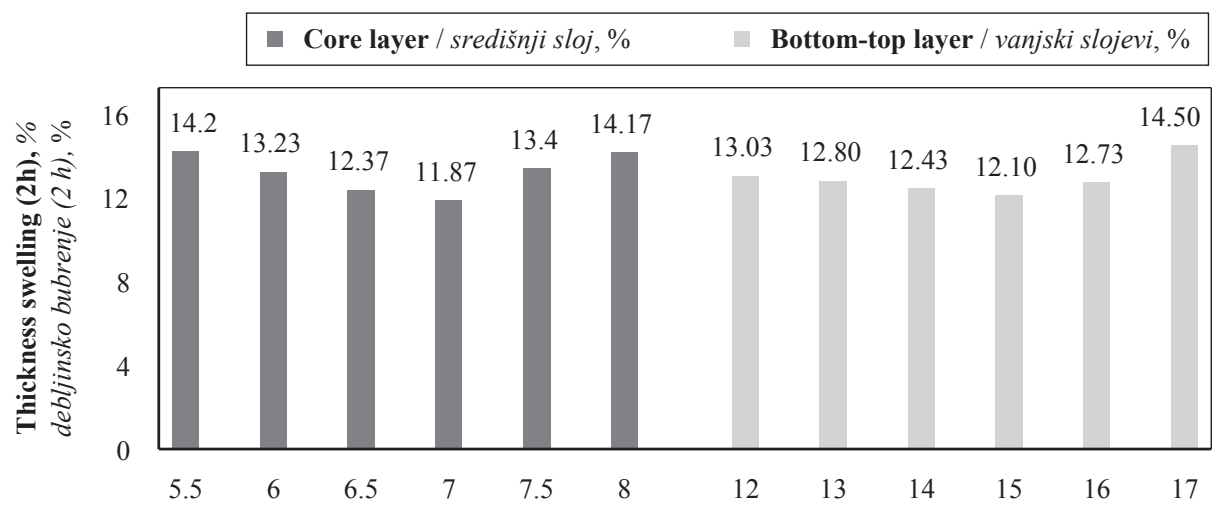

Figure 2 The effects of mat layers moisture content changes on thickness swelling (2h) characteristics

Slika 2. Utjecaj promjene sadržaja vode u slojevima ploče na debljinsko bubrenje (2h) 
... Istek, Aydin, Ozlusoylu: The Effect of Mat Layers Moisture Content on Some Properties...

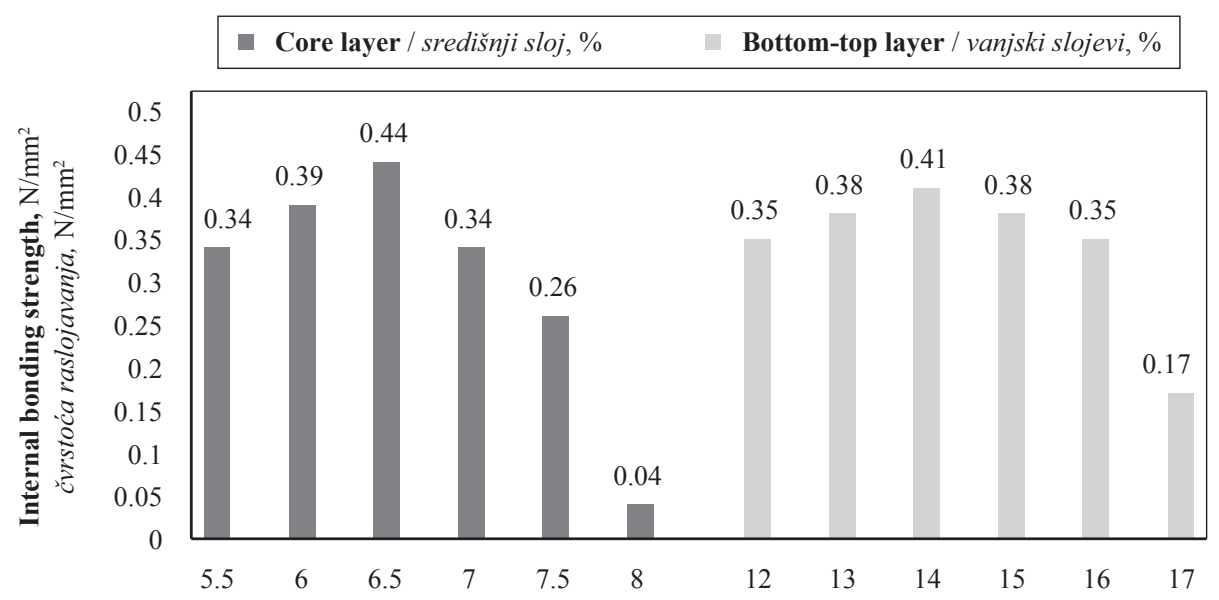

Figure 3 The effects of mat layers moisture changes on internal bonding strength

Slika 3. Utjecaj promjene sadržaja vode u slojevima ploče na čvrstoću raslojavanja

tent. Given the effect of mat moisture content change of bottom-top layer, the highest level of IB strength was observed to be $0.41 \mathrm{~N} / \mathrm{mm}^{2}$ at $14 \%$ mat moisture content. According to TS-EN 312-1 (2012), P2-class $18 \mathrm{~mm}$ particleboards should have IB strength $\geq 0.35$ $\mathrm{N} / \mathrm{mm}^{2}$. From this aspect, the highest level of IB strength was obtained at $6.5 \%$ mat moisture for core layer and $14 \%$ mat moisture for bottom-top layer. High level of moisture content at surface layers and low moisture content at core layer ensure soundness of surfaces and the increase in bending strength (BS) and MOE values, as well as the decrease in IB strength (Maloney, 1977). Moreover, with the increase of surface layers moisture from $12 \%$ to $20 \%$ and core layer moisture from $8 \%$ to $10 \%$, the IB strength increased by $10 \%$ (Bardak, 2010; Kollmann et al., 1975). The effects of mat moisture changes in particleboard production on BS are presented in Figure 4.

With the increase of mat moisture content from $5.5 \%$ to $6.5 \%$ in core layer, as seen in Figure 4 the BS of particleboard increased, while the BS decreased at 7 $\%$ and $8 \%$ moisture contents. Besides that, with the increase of mat moisture contents from $12 \%$ to $16 \%$, the BS was seen to increase, while it decreased at $17 \%$. The increase of surface layers moisture to a certain content causes the increase in surface density, hydrogen bonds, and formation of sounder surface structure.
However, the decreasing MOE strength at moisture contents equal to and higher than $17 \%$ can be explained with the non-removability of vapor from internal segments, as well as the absence of complete condensation. Nemli et al. (2007) reported that the BS values obtained at mean mat moisture of $17 \%$ was lower than the value obtained at $9 \%$ and $13 \%$ mat moisture contents in particleboards. This was explained with the damage of resin bonds on the surface layers under the effects of vapor bubbles and hot pressure (Lynam, 1969; Johnson, 1956). In a study carried out by Hus (1979), it was reported that the total moisture of mat higher than $15-16 \%$ before the pressing procedure increased the surface density, decreased the strength values, and caused the burst of board. The effects of mat moisture changes in particleboard production on modulus of MOE are presented in Figure 5. When the mat moisture content of top and bottom layer was between $18 \%$ and $20 \%$, the maximum strength was achieved and the moisture exhibited the plasticizing effect (Bardak, 2010).

As seen in Figure 5, the MOE increased with the increase in mat moisture content of bottom-top layer from $12 \%$ to $14 \%$, whereas it decreased together with the moisture content exceeding $15 \%$. Nemli et al. (2007) emphasized that the increase of mean mat moisture content of particleboards from $9 \%$ to $13 \%$ posi-

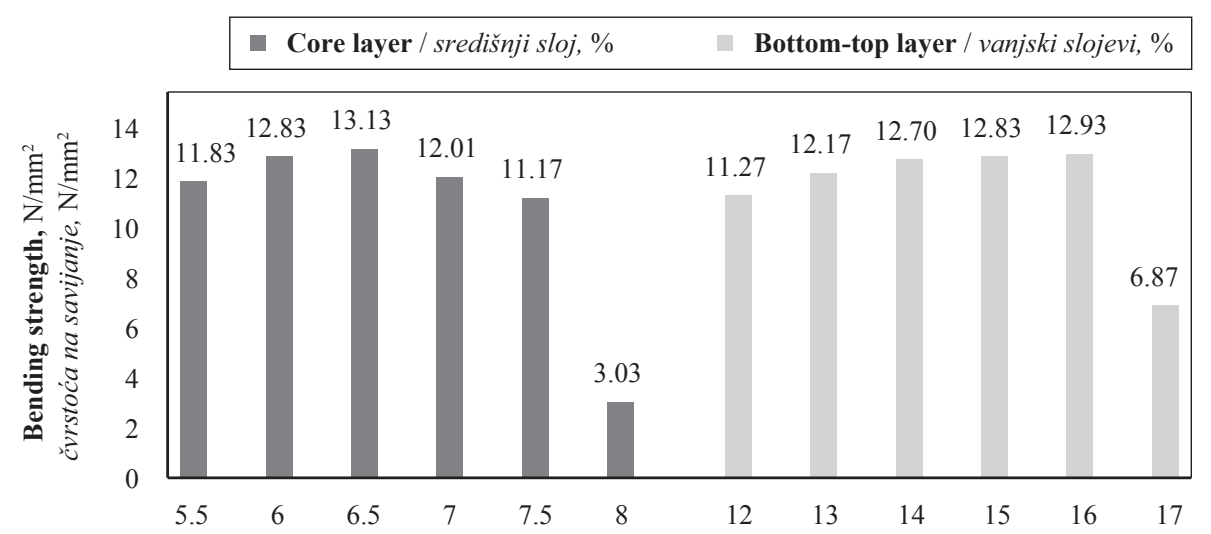

Figure 4 The effects of mat layers moisture changes on bending strength

Slika 4. Utjecaj promjene sadržaja vode u slojevima ploče na čvrstoću na savijanje 


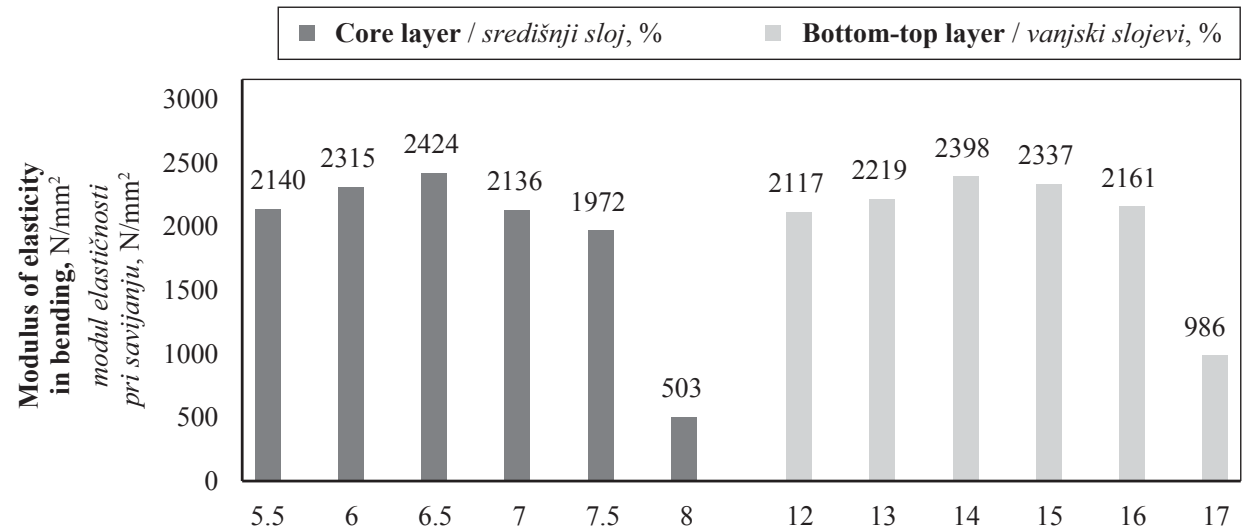

Figure 5 The effects of mat layers moisture changes on modulus of elasticity in bending

Slika 5. Utjecaj promjene sadržaja vode u slojevima ploče na modul elastičnosti pri savijanju

tively affected the MOE. According to TS-EN 312-1 (2012), the modulus of elasticity (MOE) of P2 class 18 $\mathrm{mm}$ particleboards should be $\geq 1600 \mathrm{~N} / \mathrm{mm}^{2}$. Similarly, with the increase of core layer moisture from $5.5 \%$ to $6.5 \%$, MOE of particleboards increased and then decreased at $7.0 \%$ and $8.0 \%$ moisture contents. When the moisture content exceeded $8.0 \%$, some of the particleboards were observed to be not formed. The effects of mat moisture changes on the screw withdrawal are presented in Figure 6.

In case of high moisture in surface layers and low moisture in core layer, the surface layers are compressed more than core layer, and thus the BS and
MOE levels increase in comparison to the uniform moisture samples, whereas the IB decreases. For this reason, the mean mat moisture content should be maintained within the acceptable limits in order to prevent the burst of boards after the pressing process (Maloney, 1977).

Under the production conditions of $8 \%$ and $17 \%$ core and bottom-top layer moisture contents, respectively, it was determined that the screw withdrawal characteristics do not meet the standard set in TS-EN 312-1 (2012) - the screw withdrawal of P2 class $18 \mathrm{~mm}$ particleboards should be $\geq 450 \mathrm{~N} / \mathrm{mm}^{2}$ - but they meet the standards at other moisture contents. The highest

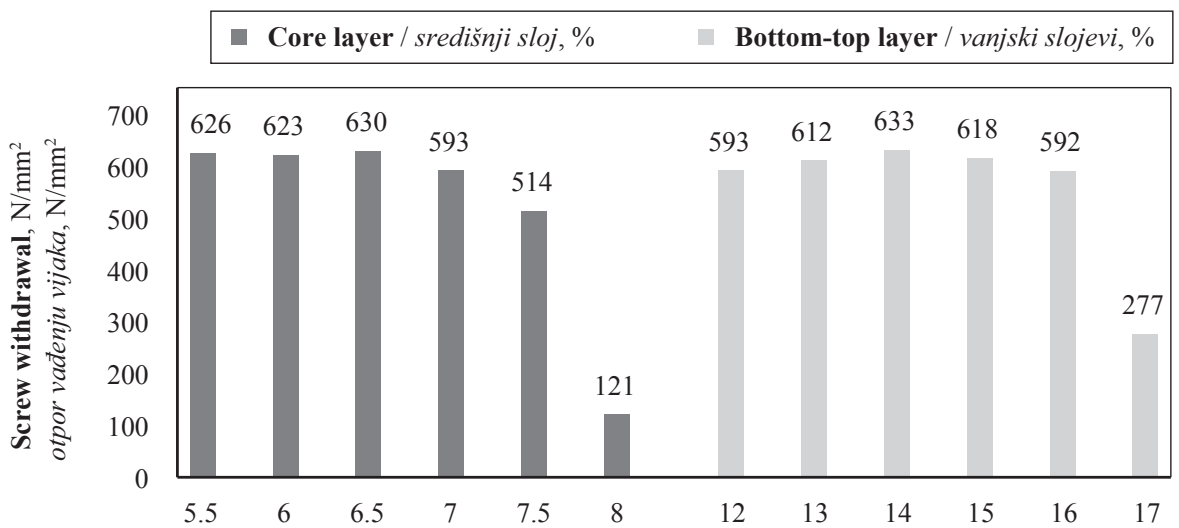

Figure 6 The effects of mat layers moisture changes on screw withdrawal Slika 6. Utjecaj promjene sadržaja vode u slojevima ploče na otpor vađenju vijaka

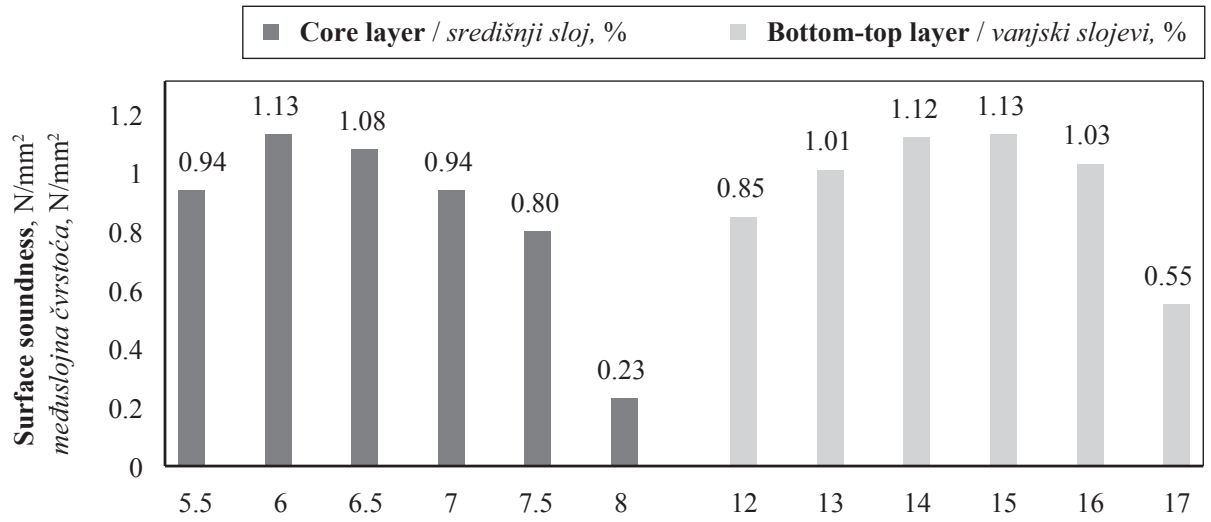

Figure 7 The effects of mat layers moisture changes on the surface soundness

Slika 7. Utjecaj promjene sadržaja vode u slojevima ploče na međuslojnu čvrstoću 
level of screw withdrawal was observed at $6.5 \%$ core layer moisture and $14 \%$ bottom-top layer moisture as $630 \mathrm{~N} / \mathrm{mm}^{2}$ and $633 \mathrm{~N} / \mathrm{mm}^{2}$, respectively. It was reported that the mat moisture content change and the press closure speed have no statistically significant effect on the screw withdrawal (Wong et al., 1998). The effects of mat moisture changes on the surface soundness values are presented in Figure 7.

Under the production conditions of $8 \%$ and $17 \%$ core and bottom-top layer moisture contents, respectively, it was determined that the surface soundness level did not meet the TS-EN 312-1 (2012) quality control standards $\left(\geq 0.8 \mathrm{~N} / \mathrm{mm}^{2}\right.$ for P2 class $18 \mathrm{~mm}$ particleboard), but they meet the standards at other moisture contents. The highest level of surface soundness value was observed to be $1.13 \mathrm{~N} / \mathrm{mm}^{2}$ at $6 \%$ core layer moisture and $15 \%$ bottom-top layer moisture.

\section{CONCLUSIONS}

4. ZAKLJUČAK

Today, the particleboards of desired quality properties can be produced by means of technology and additives used in wood-based board production. In this study, carried out in order to contribute to the production of particleboard under the production principle "low-cost and high-quality", the appropriate mat moisture contents were determined and the particleboard characteristics were expressed. Accordingly;

It was determined that the change of mat moisture content does not affect the density of boards.

It was reported that the production of particleboard is not possible in case of glued core layer moisture of $8 \%$ and above and glued bottom-top layers moisture content of $17 \%$ and above.

The water absorption and thickness swelling values of experimental boards reach at optimum moisture contents between $6-7 \%$ in core layer. However, if the core layer moisture content exceeds $7 \%$, the IB, water absorption, and thickness swelling were observed to be negatively affected.

The optimum water absorption and thickness swelling values were observed at $12-16 \%$ bottom-top layer moisture contents, while negative effects were observed on the IB strength and thickness swelling at contents higher than $16 \%$.

The highest level of BS was found to be $13.13 \mathrm{~N} /$ $\mathrm{mm}^{2}$ under the circumstances of $6.5 \%$ core layer moisture and it was found to be $12.93 \mathrm{~N} / \mathrm{mm}^{2}$ at $16 \%$ bottom-top layer moisture.

Optimum MOE was found to be around 2300$2400 \mathrm{~N} / \mathrm{mm}^{2}$ under the condition of $6-6.5 \%$ core layer moisture and $14-15 \%$ bottom-top layer moisture.

The acceptable level of IB strength was determined to be $0.42-0.44 \mathrm{~N} / \mathrm{mm}^{2}$ at $6.5 \%$ core layer moisture and $14 \%$ bottom-top layer moisture. It was determined that the results obtained at $6-6.5 \%$ core layer moisture and $12-16 \%$ bottom-top layer moisture meet the quality standards of TS-EN 312-1 (2012).
The optimum level of screw withdrawal strength was found to be $620 \mathrm{~N} / \mathrm{mm}^{2}$ at $6-7 \%$ core layer moisture contents. The interval between $12 \%$ and $16 \%$ top and bottom layer moisture contents were identified as a suitable range for screw withdrawal.

The $12-15 \%$ top and bottom layer and $6-6.5$ $\%$ core layer moisture contents were obtained as suitable range for surface soundness.

It was determined that the production of particleboard was not possible at $\geq 8 \%$ core layer moisture and $\geq 17 \%$ bottom-top layer moisture contents under the production conditions in this study. According to these findings, the ideal production conditions for particleboard quality were found to be $6-7 \%$ core layer moisture content and $13-16 \%$ bottom-top layer, when other production parameters were kept constant. Besides that, in case of $\geq 8 \%$ core layer moisture and $\geq 17$ $\%$ bottom-top layer moisture contents, it was determined that the board would burst and that quality standards could not be met during the pressing process of particleboard production.

\section{REFERENCES}

\section{LITERATURA}

1. Akbulut, T., 1998: The Effect of Formaldehyde/Urea Mole Ratio and Mat Moisture Content on Some Properties of Particleboards. Review of the Faculty of Forestry, University of Istanbul, 48(2): 23-38.

2. Bardak, S., 2010: Bazı Faktörlerin Yongalevhanın Teknolojik Özellikleri Üzerine Etkileri (The Effects of Some Factors on the Technological Properties of Particleboard.). III. Ulusal Karadeniz Ormanc1lık Kongresi (III. National Black Sea Forestry Congress), vol. V: 1887-1898.

3. Chow, P.; Zhao, L., 1992: Medium-density fiberboard made from phenolic resin and wood residues of mixed species. Forest Products Journal, 42 (10): 65-67.

4. Güler, C.; Sancar, S., 2016: The Principle of a Particle Board Plant and The Effect of Pressing Techniques on Board Quality. Düzce University Journal of Forestry, 12 (1): 1-10.

5. Hague, J.; Robson, D.; Riepen, M., 1999: MDF process variables - An overview of their relative importance. In: Proc. of the 33th Inter. Particleboard/Composite Material Symp. T. M. Maloney (ed.). Washington State Univ., Pullman, WA.

6. Hata, T., 1993: Heat Flow in Particle Mat and Properties of Particleboard Under Steam Injection Pressing. Bull. For. and For. Prod. Res. Inst., No. 80. Japan. https://doi.org/10.11501/3070413.

7. Huş, S., 1979. Teknolojik Faktörlerin Yongalevhanın Özellikleri Üzerine Etkisi (The Effect of Technological Factors on the Properties of Particleboard). Review of the Faculty Forestry University of İstanbul, Series B, 29 (2): 1-9.

8. Istek A.; Siradag, H., 2013: The Effect of Density on Particleboard Properties. International Caucasian Forestry Symposium, 932-938. (Edition No. 251261).

9. Istek, A.; Aydemir, D.; Aksu, S., 2010: The effect of décor paper and resin type on the physical, mechanical, and surface quality properties of particleboards coated with impregnated décor papers. BioResources, 5 (2): 1074-1083.

10. Johnson, E. C., 1956: Wood particleboard handbook. The industrial experimental program of the engineering. Raleigh (NC): North Coralina State College. 
11. Kollmann, F.; Kuenzı, E. W.; Stam, A. S., 1975: Principles of Wood Science and Technology. Springer Verlag, Berlin, Heidelberg, New York.

12. Lynam, F. C. 1969: Factors influencing the properties of wood chipboard. In: Mitlin L. (ed.). Particleboard manufacture and applications. UK: Press media Books Ltd.

13. Maloney, T. M., 1977: Modern Particleboard and DryProcess Fiberboard Manufacturing. Miller Freeman Publications, San Francisco-California.

14. Nemli, G.; Aydın, I.; Zekoviç, E., 2007: Evaluation of some of the properties of particleboard as function of manufacturing parameters. Materials and design, 28 (4): 11691176. https://doi.org/10.1016/j.matdes.2006.01.015.

15. Park, B. D.; Riedl, B.; Hsu, E. W.; Shields, J., 1999: Hotpressing process optimization by response surface methodology. Forest Products Journal, 49 (5): 62-68.

16. RoffaeL, E., 1982: Formalclehyclahgabe von Spanplatten und anderen Werkstoffen. DRW Verlag, Stuttgart.

17. Sanabria, S. J.; Hilbers, U.; Neuenschwander, J.; Niemz, P.; Sennhauser, U.; Thömen, H.; Wenker, J. L., 2013: Modeling and prediction of density distribution and microstructure in particleboards from acoustic properties by correlation of non-contact high-resolution pulsed air-coupled ultrasound and X-ray images. Ultrasonics, 53 (1): 157170. https://doi.org/10.1016/j.ultras.2012.05.004.

18. Sedano-Mendoza, M.; Navarrete, P.; Pizzi, A., 2010: Effect of layers' relative moisture content on the IB strength of pine tannin bonded particleboard. European Journal of Wood and Wood Products, 68 (3): 355-357. https://doi.org/10.1007/s00107-010-0452-8.

19. Wong, E. D.; Zhang, M.; Wang, Q.; Kawai, S., 1998: Effects of mat moisture content and press closing speed on the formation of density profile and properties of particleboard. Journal of Wood Science, 44 (4): 287-295. https://doi.org/10.1007/BF00581309.

20. ***TS EN 310, 1999 Wood - Based panels - Determination of modulus of elasticity in bending and of bending strength.

21. ***TS EN 311, 2005: Wood-based panels - Surface soundness - Test method.

22. ***TS EN 312, 2012: Particleboards - Specification.

23. ***TS EN 317, 1999: Particleboards and fibreboards Determination of swelling in thickness after immersion in water.

24. ***TS EN 319, 1999: Particleboards and fibreboards Determination of tensile strength perpendicular to the plane of the board.

25. ***TS EN 320, 2011: Particleboards and fibreboards Determination of resistance to axial withdrawal of screws.

26. ***TS EN 323, 1999: Wood - Based panels - Determination of density.

27. ***TS EN 326-1, 1999: Wood - Based panels - Sampling, cutting and inspection, Part 1: Sampling test pieces and expression of test results.

\section{Corresponding address:}

\section{Prof. Dr. ABDULLAH İSTEK}

Bartin University, Faculty of Forestry

Department of Forest Industrial Engineering

74100 Bartin, TURKEY

e-mail: aistek@bartin.edu.tr 